\title{
"Mostly we are White and Alone": Identity, Anxiety and the Past in Some White Zimbabwean Memoirs ${ }^{1}$
}

\begin{abstract}
KATE LAW*
Abstract Using the space created by the land invasions, over the last ten years or so there has been a proliferation of exile memoirs written by white Zimbabweans living in the diaspora, which foreground colonial nostalgia and postcolonial anxiety. This article profiles elements of this latest wave of "white (female) writing", arguing that writers such as Alexandra Fuller construct their own personal narratives based on an extremely teleological and narrow interpretation of the history of Zimbabwe. It is argued that memoirs are used as a mechanism to uphold an idealised (i.e. powerful) white identity, because whites' current "destabilised" identity has resulted in them clinging to a seemingly utopian version of both what it meant to be white and the past. The article also examines some aspects of whiteness studies, utilising Peter McLaren's framework to argue that these memoirs are beset by a whiteness of social amnesia.
\end{abstract}

$* * * * *$

"The point of looking at whiteness is to dislodge it from its centrality and authority, not to reinstate it". ${ }^{2}$

Richard Dyer, 2003.

"The whites were involuntarily putting themselves in the corner ... What worried me was that the white Zimbabwean community was not trying to partake of the total national programme; they were putting themselves into a small [separate] enclave". ${ }^{3}$

Chenjerai Hove, 2007.

In post-colonial sub-Saharan Africa, issues of white indigeneity continue to remain both highly politicised and controversial. ${ }^{4}$ In a speech to his Zimbabwe African National Union-Patriotic Front (hereafter ZANU-PF) congress in December 2000, Robert Mugabe declared that "the white man is not indigenous to Africa. Africa is for the Africans. Zimbabwe is for Zimbabweans". ${ }^{5}$ As such, history as promoted by ZANU-PF since the party assumed power in 1980, but most notably since the turn of the millennium, has developed along increasingly narrow and racialised lines, becoming contingent on "othering" groups such as white Zimbabweans. This has been done for a variety of economic, political and social reasons;

* Kate Law is Lecturer in Gender Studies at the Centre for Africa Studies, University of the Free State, South Africa and may be contacted at lawkv@ ufs.ac.za 
most notably seen with the commencement of the controversial "land programme" since 2000. As Sabelo Ndlovu-Gatsheni notes, "reverse racism became the easy way out . . . by first of all denying white settlers Zimbabwean citizenship in order to take land from them . . citizenship was [thus] redefined in nativist terms that excluded white races". ${ }^{6}$ Following the 2000 elections, in which ZANU-PF endorsed the controversial Fast Track Land Reform Program (FTLRP), by 2002 over 4,000 white families had been forced off the land. ${ }^{7}$ Legitimizing the expropriation of white owned farms by labelling them as the "Third Chimurenga" (revolutionary struggle), Mugabe claimed that by dispossessing white farmers the country was ridding itself of the lingering vestiges of British colonialism. Events within Zimbabwe surrounding the country's "land question" and ensuing "crisis" have therefore created the audience for white Zimbabwean memoirs; for whites to tell the "real" story of their alienation. ${ }^{8}$

Using the space and indeed interest created by the land invasions, over the last ten years or so exilic memoirs written by white Zimbabweans living in the diaspora have received significant levels of critical and commercial success. Thus the rejection and indeed "othering" of whiteness in Zimbabwe has resulted in a white identity crisis. Perhaps the writer to receive the greatest amount of attention is Peter Godwin, who has to date published three memoirs that detail his childhood in Rhodesia, his search for a "meaningful" white identity, and the nature of Mugabe's rule in Zimbabwe. ${ }^{9}$ Analogous to Godwin's writing, other white Zimbabweans have also written memoirs about their childhood and quest for belonging in Zimbabwe. Shifting the focus to memoirs written by women, this article profiles some of the latest examples of this "white (female) writing", by examining Alexandra Fuller's Don't Lets Go to the Dogs Tonight: An African Childhood, ${ }^{10}$ Wendy Kann's Casting With a Fragile Thread: A Story of Sisters and Africa, ${ }^{11}$ Lauren St John's Rainbow's End: A Memoir of Childhood, War \& an African Farm, ${ }^{12}$ Lauren Liebenberg's The Voluptuous Delights of Peanut Butter and Jam, ${ }^{13}$ and Cheryl Clary's Useless, Worthless, Priceless. ${ }^{14}$ This article introduces the genre qualification of white Zimbabwean exile writing, and argues that much of this writing is characterised by linear, limited constructions of self that are insufficiently mindful of history. In addition, much of this writing meditates upon what Ashleigh Harris has termed the "prelapsarian state of unquestioned belonging" that the writers felt as children in colonial Rhodesia. ${ }^{15}$ Amongst other issues, these memoirs also detail how the writers negotiate their identities as white Zimbabweans in the post-colonial period. ${ }^{16}$ Building on Tony Simoes da Silva's work on whiteness in the post-apartheid memoir, but 
shifting the focus to Zimbabwe, this article examines the ways in which white identities are understood through "an emotional rather than an intellectual understanding of White subject positions". ${ }^{17}$ In addition, this article argues that Fuller et al have chosen to construct their own version of Zimbabwe's colonial history, particularly emphasising a narrow and reductionist reading of the past that "obfuscat[es] the complexities of Zimbabwean racial history". ${ }^{18}$ For example some writers claim that it is only at Zimbabwean independence when they realise the inherent inequality of colonial Rhodesian society, thus re-centring their sense of identity and seemingly "shedding" the racism of colonial society. Rather I argue that white female identities are only somewhat reconfigured in the aftermath of the controversial "land reform" programme, as ZANU-PF"s identification of white Zimbabweans as unwanted aliens opens up a dialogic space in which the writers grapple with their sense of belonging, citizenship and whiteness in the diaspora.

In what follows, this article briefly sketches the history of colonial Rhodesia from 1965-1980. It then moves to examine the development of whiteness studies and some of the valuable theoretical questions that the discipline raises for historians studying the transition from colonial to post-colonial societies. The article then explores the ways that whiteness has been represented as what Peter McLaren has termed a whiteness of "social amnesia" in the memoirs above, and argues that Fuller et al construct their own personal narratives based on an extremely teleological and thus narrow interpretation of the history of Zimbabwe, particularly in reference to their representation of the country's liberation struggle. ${ }^{19}$ In doing so this article further comments upon what Brian Raftopoulos has observed as "the inscri[ption] of victimhood on white identities" in the post-colonial memoir. ${ }^{20}$

\section{Rhodesia 1965-1980}

In an attempt to stall the "wind of change" that had already begun to sweep the African continent, on 11 November 1965 Rhodesian Prime Minister Ian Smith declared illegal independence (UDI) from Britain. Many members of the international community (Britain included) quickly condemned Rhodesia's actions, but denunciation and economic sanctions were the extent of the reprisals. ${ }^{21}$ During the late 1960s and early 1970s Britain and Rhodesia were in regular dialogue to try and find terms that would end the rebellion. However, Smith and the Rhodesian Front (RF) were unwilling to make concessions to enfranchise Rhodesia's six million black population. ${ }^{22}$ Although there had been isolated incidents of guerrilla warfare since UDI had been declared, the attack on Altena 
farm in December 1972 is widely seen as the beginning of the Second Chimurenga, signalling an upsurge in insurgent activity. ${ }^{23}$ Despite the fact that Rhodesia had been embroiled in a war for fourteen years, the eventual coming of Zimbabwean independence in April 1980 did not come through the barrel of the gun. Rather, Zimbabwean independence was achieved through negotiation at the Commonwealth summit in Lusaka in August 1979 and at the Lancaster House conference in London. ${ }^{24}$ In an attempt to secure the position of whites in the post-colonial dispensation at the conference it was agreed that land could only be sold on a willing buyer - willing seller basis and thus there would be no mass expropriation of white owned land. Consequently the negotiated settlement, for at least the first ten years of independence, forced the new government to compromise its ambitions, and to a certain extent serve white interests.

To employ Karin Alexander's terminology, however, white Zimbabweans thought of themselves as "orphans of empire", feeling betrayed by Britain and afraid of the prospect of black majority rule. ${ }^{25}$ Much of this anxiety rested on whites' (often very limited) understanding of the nature of the post-colonial transition and centered on the worry that a black government would pursue policies based on retribution. As Josephine Fisher notes, "the white community appears to have been mentally unprepared caught on the wrong foot as it were - at the end of the war". ${ }^{26}$ Whites were also seemingly "caught on the wrong foot" when Robert Mugabe and ZANU-PF won 57 out of 80 seats in the 1980 election. Indeed, as Peter Godwin and Ian Hancock have noted, this inability to foresee that the leaders of the liberation struggle would emerge victorious through the ballot box occurred largely because "most white Rhodesians had become so accustomed to hearing what they wanted to believe . . . that they were often incapable of distinguishing between the ephemeral and the substantial, between fantasy and reality". ${ }^{27}$

As independence dawned, in a televised speech in March 1980, Mugabe urged Zimbabweans, "whether you are black or white, to join me in a new pledge to forget our grim past, forgive others and forget, join hands in a new amity, and together as Zimbabweans ... . work hard to reconstruct and rehabilitate our society". ${ }^{28}$ Warned by Mozambique's president Samora Machel of the destabilising effects of white flight, Mugabe thus tried to allay white fears and anxieties; indeed as Ibbo Mandaza notes, the state's reconciliation policy "sought to embrace anyone who was willing to be liberal enough". ${ }^{29}$ Consequently in April 1980, many white Rhodesians were simultaneously trying to comprehend this "new world order" whilst also exploring their nascent Zimbabwean 
identities. One possible framework for exploring and historicising the development of these new identities is through the critical interrogation of whiteness.

\section{Understanding "White" and "Whiteness"}

The attempt to redefine and problematise white identities gained particular traction in the North American academy with scholars arguing that "whiteness" was socially constructed, ${ }^{30}$ with one of the principal conceits of whiteness studies centring on the differentiation between "white" and "whiteness". Some of the initial literature concerning whiteness studies consequently attempted to deconstruct and thus dehegemonize what it meant to be white, with the recognition that to be white is to also possess a racial identity. ${ }^{31}$ As Richard Dyer argues, "the invisibility of whiteness as a racial position in white (which is to say dominant) discourse is of piece with its ubiquity". ${ }^{32}$ Consequently for Dyer, whiteness challenges the sense of whites as a non-raced group. Similarly, Ruth Frankenberg argues that white people are "raced" just as men are "gendered" ${ }^{33}$ For Frankenberg, "whiteness is a location of structural advantage, of race privilege. Second, it is a 'standpoint', a place from which people look at ourselves, at others, and at society. Third, 'whiteness' refers to a set of cultural practices that are usually unmarked and unnamed". ${ }^{34}$ Scholars working on white identities in other "peripheries" such as South Africa and Zimbabwe often came to whiteness studies through the broader theoretical lens of postcolonial studies, as they attempt to unpack the effects that the shift from the colonial to postcolonial has had on white identities. ${ }^{35}$ Southern African white identity/whiteness scholarship has thus primarily focused on two interrelated issues. In the first instance, scholars such as Rory Pilossof have emphasised the ways in which white colonial identities remain unreconstructed and embedded in postcolonial dispensations. ${ }^{36}$ Further commenting on the enduring permanence of white identities in South Africa following the dismantling of apartheid, Melissa Steyn argues that "whites have tended to take their identity as ... standard ... this makes white identity invisible ... white people have been able to ignore the manner in which the notion of race has structured people's life opportunities in society as a whole". ${ }^{37}$ In addition, according to Leon de Kock, "whiteness has become so delegitimised by virtue of its complicity with apartheid that it has often been rendered 'blank', a taken-for-granted negative essence". ${ }^{38}$ For de Kock, whiteness "had developed in a dialectical relationship with 'wildness,' partly because whiteness had defined itself in opposition to wildness". ${ }^{39}$ Indeed the symbiotic relationship between 
whiteness and landscape is a crucial component to many white writers' sense of identity in both the colonial and post-colonial memoir. ${ }^{40}$

The second broad issue examines the extent to which white identities have been changed in the postcolonial period. In South Africa, notions of whiteness were, in some senses, redefined in the wake of the end of apartheid in 1994. In one instance at least, this redefinition found public expression in the establishment of the Truth and Reconciliation Commission (hereafter TRC) in 1995, following the first democratically held election in the country's history. Many writers cited the TRC as an essential component of a successful transition to democracy in the country. ${ }^{41}$ For Michael Chege, writing shortly after the transition to majority rule, "nearly one hundred years after the Boer War, the meaning of whiteness in Africa is in flux ... what the white minorities of countries such as Kenya, Mozambique, Namibia, South Africa, Zambia and Zimbabwe are discovering fitfully is the necessity of making peace with the idea of Africa". ${ }^{42}$ Consequently within the literature that explores whiteness in Southern Africa, an important interrelated theme is that of "transitioning"; of white Africans "becoming" African. While in a post-colonial setting a redefinition of whiteness as an African identity "may seem to be an appropriate and commendable way of rethinking whiteness", ${ }^{43}$ a large proportion of this emergent literature does suffer the occasional lapse into myopia, with scholars indulging their own sense of whiteness in their writings. For example as Samantha Vice opines: "whites in South Africa ought to see themselves as a problem. How does one live knowing this, among the very visible effects of one's moral offenses?"44 Yet philosophers such as Vice are not the only guilty parties here. When discussing the works of Alexandra Fuller, Deborah Seddon wrote that she was "three years younger than Fuller, I grew up in Rhodesia/Zimbabwe at the same time. Her first book [Dogs] proved to be a painful but rewarding return to the interior landscapes of my own childhood". ${ }^{45}$ Criticisms of writers such as Vice and Seddon are not to render the historian as blameless. Indeed many historians have adopted the word "whiteness" without interrogating its construction or defining it adequately; in sum they use the term with little sophistication. Thus, echoing the work of Leigh Boucher, Jane Carey and Katherine Ellinghaus, I too register a "profound discomfort with the way that whiteness has snuck through the backdoor into the historian's toolkit, often with little definition or explanation". ${ }^{46}$ Yet as Angela Woollacott observes, "historians can, quite specifically, shed light on how whiteness has been constructed as a dominant and normative racial category, in specific times and cultural contexts, and therefore have a crucial role to 
play in whiteness studies". ${ }^{47}$ Attempting to further understand these related issues, this article draws on some of the back catalogue of whiteness literature (which raises valuable theoretical questions), in an attempt to understand the linkages between colonial nostalgia, postcolonial anxiety, white identities and belonging in the memoirs discussed below.

\section{Memoirs, "Patriotic History" and "White Writing"}

From the writing of women such as Sheila MacDonald, Gertrude Page and Cynthia Stockley who illustrated the rituals of the colonial milieu, through to the anti-colonial novels of Doris Lessing, there is an established tradition of white women writing about identity, race and landscape in colonial Zimbabwe. ${ }^{48}$ One way that discussions about white identities in South Africa and latterly in Zimbabwe have begun to find expression relates to the construction of whiteness in autobiographies and "other narratives of the self". ${ }^{49} \mathrm{By}$ examining the works of writers such as Fuller et al this article explores elements of what could be considered the latest evolution of Zimbabwean "white writing", which according to Ranka Primorac has "not been officially recognised as a part of Zimbabwe's literary canon".$^{50}$ Despite the fact that these works may not be treated with hagiographic reverence, events within Zimbabwe, namely the issues surrounding the country's "land question" that have developed since 2000 , have simultaneously created an interest in white Zimbabwean memoirs. ${ }^{51}$ I contend that memoirs are used as a mechanism to uphold an idealised (i.e. powerful) whiteness, because whites' current "destabilised" identity has resulted in them clinging to a seemingly utopian version of both whiteness and the past. Discussing the genre particularities of memoirs, for Tony Simoes Da Silva, "given the retrospective nature of the memoir, its appeal lies in allowing authors engaged in a negotiation of subject identities buffeted by a raft of life forces, personal and political to articulate their anxieties about the present". ${ }^{52}$ Thus memoirs become instruments through which to index broader kinds of historical change.

Varying in both range and quality, all the memoirs apart from Clary's were distributed by international publishing houses and were clearly marketed within the growing interest for stories about "Africa" ${ }^{53}$ Furthermore this "Africa" is conceptualised as a wild, vast pastoral landscape that is seemingly full of open spaces, wild animals and limitless adventures. ${ }^{54}$ While the existing scholarship on Zimbabwean "white writing" has mostly focused on the relationship between the landscape and white identity formation, scant attention has been paid to how the settler community "imagined" 
the liberation struggle and how writers such as Fuller et al negotiated their position as white Africans in the immediate postcolonial period. ${ }^{55}$

\section{"Who Would Want to Fight With Us?"56 White Understandings of the Liberation Struggle}

A striking feature of many of the works written since 2000 regarding the liberation struggle of the 1960s and 1970s is that many writers fail to understand that the war was a struggle for democracy and self-determination. In an interview in 2006, discussing her then new book Scribbling the Cat, ${ }^{57}$ Fuller commented that:

\footnotetext{
"In Dogs, what I wanted to show people is that if you're a kid in war you have no idea what's going on. You try to make sense of it the best you can, but you really can't explain it; you don't have a vocabulary for it yet. I put in a little bit of history in the first book so readers could orient themselves, but I slipped out of my voice to do that. I took off the clothes of the child and slipped into my adult voice, saying, 'Here, for the record, is what was going on'. But as a kid you don't understand that, so there was no real forum for me to write about politics". ${ }^{58}$
}

However, for the most part, Scribbling details the likes of "K", a white ex-soldier who suffers from Post Traumatic Stress Disorder, and Fuller's own quest for belonging and a "meaningful" identity in Africa. ${ }^{59}$ As is subsequently shown, many writers failed to engage with the war beyond their own immediate and limited understanding of it. While it is true that many of the writers were children when the liberation struggle occurred, the limited ahistorical understandings they employ act as exculpatory devices. ${ }^{60}$ For Harris, writing from this perspective, "allows the writer[s] to imagine a space of political and racial innocence and naïveté, a prelapsarian state of unquestioned belonging as a white child ... It would appear that the narration of one's childhood experience in a place that denies one's belonging . . . becomes a means to inscribe one's self into the historical, political, and geographical landscape of Zimbabwe" ${ }^{61}$ Thus these exile memoirs are characterised by problematic, linear readings of the past.

Recalling how the liberation struggle was conceptualised by white society, Fuller states that "the whites didn't call it Chimurenga. They called it 'the troubles', 'this bloody nonsense'. And sometimes 'the war'. A war instigated by 'uppity blacks', 'cheeky kaffirs', 'bolshy muntus', 'restless natives', 'the houts' ". ${ }^{62}$ Fuller's failure to examine, even briefly, the reasons why the war was being waged is part of a set of disconcerting silences that many of the works outlined above share. For St John, "the War began in earnest the day that Miss North told us one of our classmates had shot himself 
dead in the night. His father was away on army call-up and he'd been trying to be the Man of the House. A loaded rifle lay on the rug beside his bed. He'd got out of bed and stepped on it . . . for the first time there was a feeling that we were a nation at War". ${ }^{63}$ She notes further that "even as it [war] edged nearer and nearer to us and became ever more threatening, [it] had always been at one's step's remove from us. At school we talked about it, we were afraid of it, it occupied most of our waking thoughts, but it was unreal and surreal". ${ }^{64}$ While St John observes the visceral, physical and psychological space that the war occupied within the white population, like other writers who romanticise the landscape, she keenly feels the "drama" of war. She describes how she "felt like everything I'd ever done had been leading me to this point. That I'd sleepwalked through life till now. That this was worth fighting for and, yes, worth dying for". ${ }^{65}$ Furthermore, for St John war literally defined who she was, as "when you fully expect a grenade attack at any moment, when every goodbye could be your last... death, fear, heroism and loss shape your days as well as your responses". ${ }^{6} 6$ Similarly Cheryl Clary states that, "we lived by extremes, and did everything in a frenzied sort of way, always as if it was the last . . . this gave us a sense of living life to the full". ${ }^{67}$ Moreover for Clary, the war meant that:

"nobody was prepared to leave, to find a safer place, we would stay and we would gather strength, and we would adapt to this new way of life . . we continued our lives as best we could, in a defiant way I suppose. With all the risks attached we were stubborn, and continued to go to our old picnic spots, isolated and dangerous as they were, and we became blasé, [taking] each day for what it was [as] tomorrow might never come". ${ }^{68}$

Yet Clary's understanding of the causes of the war remained fairly limited as she recalls, "there was a lot of talk during the year about what was going on in the country, I didn't understand much because conversation stopped when I walked into the room, and it was all talked about behind closed doors and in quiet voices. We talked about it in school, and it seemed all our parents were worried, about the start of the war, not here surely, who would want to fight with us?" 69 While Clary has chosen to "desist from politics of any kind" in her story, such a decision appears peculiar considering that, like other writers, such as St John, Clary felt that war, by definition a political act, defined her very being. ${ }^{70}$ Such a decision is perhaps telling of the myopic understanding that many white Rhodesians employed of the war. Furthermore it seems something of an oxymoron that the concept of war could be so tangible and palpable (to the writers) and yet so misunderstood. Indeed the hubristic nature of settler society buffered and thus negated the 
effects of the war on white Rhodesians. As Fuller opines, "it is such a surprise when we lose the War". ${ }^{71}$ Furthermore as Kann observes, "no-one in my generation recognized that we were fighting a war to preserve an unstable way of life". ${ }^{72}$ As discussed earlier in the article, the loss of the war and the coming of Zimbabwean independence was met with puzzlement by the white community. As St John explains:

"for me it was the euphoria that was the giveaway. That and the fact that I'd only recently registered the name of Mugabe, and yet every black person in Zimbabwe seemed to have known about him for years ... I had believed we were fighting against communism, [the war] had turned out to be someone else's war of freedom. We were the terrorists. Our heroes were not heroes at all, they were evil racists. Only black people were allowed to be heroes". ${ }^{73}$

By the same token, Fuller suggests that "there are, it turns out, no white war heroes. None of the army guys for whom I cheered and prayed will be buried at Heroes Acre under the eternal flame. They will not have their bones dug up from faraway battlefields". ${ }^{74}$ It is clear that the war enveloped the lives of writers such as Fuller, St John and Clary, with its outcome highlighting the bewilderment that the transition to majority rule entailed, the first marker of an increasingly "disoriented" white identity. One way this anguish is further expressed is in the ways that many writers grapple to make sense of themselves as white Zimbabweans, with questions of "belonging" never far from their minds.

\section{Whiteness and "Belonging"}

Following the transition to Zimbabwean independence, notions of whiteness, particularly issues regarding whether a white Zimbabwean identity can be constructed, figure prominently in the works of Kann, Liebenberg, Fuller and St John. Kann et al struggled to negotiate their new de facto identity, not only as white Zimbabweans but also as white African; it is at this stage that the writers identify as having a sense of unease or discomfort with their whiteness. ${ }^{75}$ They are all seemingly bewildered at the outcome of the liberation struggle, something that only serves to complicate their own sense of identity. As St John observed, "overnight our way of life ended. The culture that had grown up around the war . . was eradicated in an instant and all that was left was a dawning realization of what had taken place. It was like going to sleep in Jamaica and waking up in the pages of Orwell's 1984. All my life I'd been taught to value and hold sacred the name of Rhodesia and blood ties that bonded me to it". ${ }^{76}$ Furthermore, "[t]he sense of disillusionment I felt was total. The country I had loved so much 
that at times I almost wished I could die for it was not the country I had thought it was. We had repressed people, oppressed people, tortured people and murdered people for the worst possible reasons: the colour of their skin". ${ }^{77}$

Similarly Fuller recalls that, "there are freeanfair elections in February 1980, just before my eleventh birthday, and we lose the elections. By which I mean our muntu" ${ }^{78}$ As Liebenberg comments, the outcome of the war meant that "we have lost it all ... It's comrade Mugabe who's taken it. I saw him on TV, swearing an oath. There is going to be peace and freedom now. Dad says his speech was a bunch of Cold War rhetoric. The air is charged with static and some of the farm Afs [Africans] eye Dad with a new resentfulness". ${ }^{79}$ Following independence the Fullers moved to Malawi then finally to Zambia. Shortly after arriving in Malawi, the Fullers' sense of social dislocation is felt keenly, as Fuller describes:

"we feel more dangerously, teetering close to disease and death (in a slow, rotting, swamp-induced fashion) than we did during the war in Rhodesia where there was a zinging, adrenaline filled, anything-goes freedom and where we were surrounded by violent, quick mutilation and a sudden, definitive end. Which now seems preferable to death by swamp rot. Death by spies. Death by lack of social contact". 80

This, she notes, only served to exacerbate the feeling of being "white and alone" ${ }^{81}$ Fuller's first sense of her whiteness occurs at the end of the war when education is desegregated. She recalls that:

"the blacks laugh at me when they see me stripped naked after swimming or tennis, when my shoulders and arms are angry sunburnt red. 'Argh! I smell roasting pork!' they shriek. 'Who fried the bacon?' . . . My God, I am the wrong colour. The way I am burned by the sun, scorched by flinging sand, prickled by heat . . . The way I stand out against the khaki bush like a large marshmallow to a gook with a gun. White. African. White-African. 'But what are you?' I am asked over and over again. 'Where are you from originally?' "82

For St John, "my whole life was a lie, I'd been brainwashed politically and was blind in almost every other way and I had to reprocess everything from a different position". ${ }^{83}$ She notes further that "my identity was gone, and [that] the shock was overwhelming". ${ }^{84}$ Once she got over this "shock" she "opened my ears and my heart and, not without trepidation, let Africa come flooding in". ${ }^{85}$ Without any hint of irony, St John explains how that accepting her African identity allowed her to "love them and to love their culture". ${ }^{86}$ In accordance with J. M. Coetzee's dictum that following the end of apartheid whites were no longer European, not yet African, ${ }^{87}$ St John also discusses the transience of her sense of identity; "it was getting harder and harder for me to live with what I now knew to be the reality of our former lives. I felt caught 
between two worlds: an African world which, because of the past, I might never truly be part of, and my own world, to which I found it increasingly hard to belong". ${ }^{88}$ It is interesting to note that as a Rhodesian, Kann had been very clear about her identity; "patriotic passion was palpable and I breathed it in eagerly ... I revelled in those moments of knowing exactly who I was: a young Rhodesian girl with sun kissed shoulders and a Farrah Fawcett hairdo, ready with my family, to take on any red-eyed Communist who loomed on the hill, not for a minute noticing the cautious black waiters who cleared away our glasses and plates". ${ }^{89}$ Yet she failed to feel the same confidence in her nascent Zimbabwean identity; "I took a deep gulp of dusty African air. I was now a Zimbabwean girl. Zim-bab-we-an. It even sounded sweaty and African, like a dirty top-heavy bus, or twangy music on a thumb piano. I tried on different variations - a Zimbo, a 'Babwean' - shifting my shoulders, holding my tummy in, looking for something that felt becoming and comfortable". ${ }^{90}$

However, despite this discomfort, Robert Mugabe's reconciliatory rhetoric assuaged much of the fear of the white community. As St John observes:

"once they found that life could, in essence, continue as before, the Rhodies returned to their booze cruises on the Zambezi and Lake Kariba . . . they went on shooting elephants, fly-fishing in Inyanga, plying their beer bellies with Castle lagers and T-bone steaks and dividing along gender lines at generous-spirited, camaraderie-warmed braais. They replaced their 'Rhodesia is Super' shirts with 'Zimbabwe' baseball caps and the country became a sunny paradise again. And if now there were more black faces in restaurants, on golf courses and in holiday resorts than there were white, well, that made it even more of a paradise because it had become an inclusive paradise". ${ }^{91}$

Thus in the 1980s for many whites, whiteness often remained an unconscious part of their identity because of ZANU-PF state rhetoric. Similarly in an interview Kann noted that "suddenly life was literally shockingly quiet. It was confusing because there were none of the predicted horrific, primitive and brutal outcomes of having Africans in charge". ${ }^{92}$ Thus to many whites, Mugabe's rhetoric designated that their lives could continue almost unchanged. As Harris argues, "the ambiguity between white exculpation and redemption in narrativising the past is exacerbated in a contemporary Zimbabwean context in which Robert Mugabe's early statements of national reconciliation have given way to overt threats to white Zimbabweans' sense of belonging". ${ }^{33}$ Yet this is not to underemphasise the decision of many whites to actively disengage from various manifestations of the Zimbabwean post-colonial state. In an interview with Kann she argued that, " 'Whiteness' in Africa 
always felt very, very vulnerable (ironically). It was only powerful in numbers and when those numbers included more than one white man (ask any white woman alone in a black area). After Independence this sense of vulnerability increased and the unspoken answer to it was to hunker down behind high walls and keep a low profile". ${ }^{94}$

In Rainbow's End, St John notices the continued insularity of white society shortly after independence, that "at braais it made me cringe to hear whites making racist remarks while they were in the presence of or being served by a black person. Some had retreated into Rhodie enclaves from the safety of which they made tasteless jokes about the jonge (cock) symbol of Mugabe's Zanu-PF party". ${ }^{95}$ Yet Kann does note that "others ... enthusiastically welcomed Zimbabwe's new multiculturalism, but after years of social conditioning, found it tricky to do it in a way that didn't come over as patronizing". ${ }^{96}$ Consequently while Zimbabwean independence may have helped, in a limited sense, to decentre hegemonic notions of whiteness amongst the white population, as Chennells' work on myth has shown, the hubristic nature of white society negated many aspects of these changes. ${ }^{97}$ Thus from a reading of the memoirs in this piece whiteness reasserted itself after 1980 only to be shattered after 2000. In addition, some twenty years later the land occupations appeared unforeseen for many white Zimbabweans because, as McDermott-Hughes has explored, they chose to negotiate their identities with land rather than social forms. ${ }^{98}$

Notions of whiteness also manifest themselves through explorations of a white Zimbabwean identity in the diaspora, as all five writers battle with their identity in their self-imposed exile. Kann moved to New York City in the early 1980s with her American husband Mickey. Discussing her arrival she recalls that:

"a path diverted, a faucet of tears turned off. Americans are without a mental image of Zimbabwe, and in its place are only fumbled associations . . . It's difficult even for people who live in Africa to see the continent clearly. Our heads are so choked with images of white foreigners adventuring under a romantic sun or haunted black children with distended bellies teetering on skeletal legs that myth tangles itself up with truth". ${ }^{99}$

Kann notes further that when she arrived in New York she "put aside my Zimbabwean identity". ${ }^{100}$ Similarly Fuller explores the complexity of her identity, as she notes " 'I'm African'. But not black. And I say, 'I was born in England' by mistake. But, 'I have lived in Rhodesia (which is now Zimbabwe) and in Malawi (which used to be Nyasaland) and in Zambia (which used to be Northern Rhodesia) ... What does that make me?" 101 Thus for Fuller, "my soul has no home. I am neither African nor English, nor am I of the 
sea" ${ }^{102}$ Fuller's sense of an African identity is heavily influenced by her mother's sense of African-ness, as she explains, that "mum is African in her orientation, so we think of ourselves as African. She believes herself to be a million percent Highland Scottish in her blood ... My siblings and I are more than half English but this is hardly ever acknowledged". ${ }^{103}$ Additionally once Fuller moves to America, her mother believes that she is "contaminated by my American ordinariness, condemned for my disloyalty, my veins are the equivalent of a genetic tourniquet. I am not a million percent Highland Scottish. I am not tribal. I have no patience with nostalgia. I've relinquished wonderful Old Africa and crossed the Atlantic to join the dull New World". ${ }^{104}$ Consequently it is clear that the quest for belonging features prominently in the works of Fuller et al, with many writers retrospectively using Zimbabwean independence as a watershed to redefine their sense of identity and thus refocus their sense of whiteness, often finding a sense of refuge, however awkward, in their global whiteness in the diaspora. Yet while many writers recast their notions of whiteness and thus identity in the space that independence created, a sense of belonging and fit within Africa continues to elude them. As Fuller notes, "now how can we, who shed our ancestry the way a snake sheds skin in winter, hope to win against this history? We mazungus. We white Africans of shrugged-off English, Scottish, Dutch origin”. ${ }^{105}$ Thus in many senses whiteness survives and remains embedded in the immediate post-independence denouement, only being challenged and reoriented during the "Third Chimurenga".

\section{Conclusions}

Although none of the memoirs discussed in this article are written by women who have lost land since the commencement of what Mugabe has termed the "Third Chimurenga", this disruptive episode and concomitant identification of white Zimbabweans as enemies of the state has prompted writers such as Kann and Fuller to reflect on issues such as belonging, race and identity in the post-colonial state. Central to many of the memoirs discussed are the issues of white belonging and indigeneity that refract onto debates about the nature of citizenship in post-colonial Africa. ${ }^{106}$ Questions surrounding whiteness and indigeneity continue to remain highly controversial and politicised issues in post-colonial African countries such as Zimbabwe and South Africa. As part of his 2009 presidential campaign, and possibly to counteract the negative press surrounding his singing of the liberation struggle song Umshini wami ("Bring me my machine gun"), South African President Jacob Zuma was reported to have suggested that "of all 
the white groups that are in South Africa, it is only the Afrikaners that are truly South Africans in the true sense of the word . . U Up to this day, they [the Afrikaners] don't carry two passports, they carry one. They are here to stay". ${ }^{107}$ Thus Zuma appropriated a discourse centring on white belonging, reinforcing Afrikaners' sense of white identity by marginalising other whites who also lay claim to being white Africans. This issue speaks to a related set of problems in which white African experiences have, for the most part, yet to be integrated into the discourses of post-colonialism; doing so would challenge the nascent nationalist ideologies and histories that have proliferated since the end of empire. Attempting to bridge this divide, this article has highlighted both the white identity "crisis" and the "highly problematic readings of the past" that are prominent features of the exile memoirs above. ${ }^{108}$

Currently within Zimbabwe, issues of white indigeneity and belonging continue to remain controversial. As one writer for the state controlled Herald, Nathaniel Manheru, put it in July 2012, the term "white African" is an "oxymoron so much in vogue for Rhodesia's erstwhile privileged whites when they seek to stake a claim in post-independence Zimbabwe". ${ }^{109}$ Reflecting further on the white-penned memoirs, for Manheru, "you are struck by their acute assertion of their claim to the land . . . they will laboriously tell you about places, about the flora and fauna ... but to have to assert your rootedness against a black indigene who has no other root, no other place, no other country ... it amounts to inventing nationality". ${ }^{110}$ While it is clear that Manheru's assessments are unduly critical, the memoirs discussed above do offer narrow, ahistorical interpretations of Rhodesian and Zimbabwean history, demonstrating that there is an incomplete and thus unfinished discussion regarding what Jonathan Jansen terms the "reframing [of] victors and villains". ${ }^{111}$

Through exploring this latest wave of "white writing", this article takes steps towards understanding white identity anxieties following the transition to independence in 1980 and the commencement of the controversial land "invasions" at the turn of the millennium. Following on from Rory Pilossof's work on the white farming community, this article intends to further open up space for a more nuanced discussion of white identities in Zimbabwe. ${ }^{112}$ In doing so it may hopefully serve as a springboard for other historians to map the connections and confluences between the consolidation of imperial power, colonial whiteness and post-colonial subjectivities since the founding of the country in 1890, further commenting on Frederick Cooper and Ann Stoler's suggestion that the white aspects of colonial and post-colonial societies are often afforded an unwarranted coherence. ${ }^{113}$ 


\section{Notes}

${ }^{1}$ I would like to thank Jane Carey, Andrew Cohen, Daryl Gowlett, Nadine Lake, Ian Phimister, Neil Roos, Andrew van der Vlies and the three anonymous reviewers for their valuable feedback. Needless to say, all errors remain my own.

${ }^{2}$ R. Dyer, "The Matter of Whiteness", in M. S. Kimmel and A. L. Ferber (eds), Privilege: A Reader (Colorado, Westview Press, 2003), p. 24.

${ }^{3}$ Chenjerai Hove interviewed by Ranka Primorac, "Dictatorships are Transient" (June 2007), available at http://www .weaverpresszimbabwe.com/interviews/239-interview-chenjerai-hove-by -ranka-primorac-.html, retrieved on 21 September 2010.

4 To see how this is playing out in the South African academy see N. Roos, "Critical Whiteness and worried white scholars - some reflections on Whitewash", forthcoming 2014.

5 As quoted in A. Norman, Mugabe - Teacher, Revolutionary, Tyrant (Stroud, History Press, 2008), p. 110.

${ }^{6}$ S. J. Ndlovu-Gatsheni, Do "Zimbabweans" Exist? Trajectories of Nationalism, National Identity Formation and Crisis in a Postcolonial State (Bern, Peter Lang, 2009), p. 276.

${ }^{7}$ D. McDermott-Hughes, Whiteness in Zimbabwe: Race, Landscape and the Problem of Belonging (Basingstoke, MacMillan, 2010), p. xi. For figures on land holdings see R. Palmer, "Land Reform in Zimbabwe, 19801990”, African Affairs, 89 (1990) pp.163-181.

8 For more on this see R. Pilossof, "The Unbearable Whiteness of Being: Land, Race and Belonging in the Memoirs of White Zimbabweans", South African Historical Journal 61.3 (2008), pp. 621-638. Between 1976 and 1982 60\% of Rhodesia/Zimbabwe's white population emigrated. These "orphans of empire" left the country for material and personal security or simply were "too 'Rhodesian' to tolerate the transformation of their country into Zimbabwe". See P. Godwin and I. Hancock, Rhodesians Never Die: The Impact of War and Political Change on White Rhodesia c. 1970-1980 (Oxford, Oxford University Press, 1993), p. 287.

${ }^{9}$ P. Godwin, Mukiwa: A White Boy in Africa (London, Picador, 1997); When a Crocodile Eats The Sun (London, Little Brown, 2006); The Fear: Robert Mugabe and the Martyrdom of Zimbabwe (London, Pan MacMillan, 2011).

10 A. Fuller, Don't Let's Go to the Dogs Tonight: An African Childhood (London, Picador, 2000). Dogs tells the story of the Fullers, narrated by Alexandra Fuller (known as Bobo). The memoir explores Fuller's relationship with her family, whose lives are punctuated by the deaths in infancy of Fuller's siblings Adrian, Olivia and Richard. The memoir also explores life as a child during the liberation struggle, and Fuller's attempts at finding "belonging" in post-colonial Africa.

${ }_{11}$ W. Kann, Casting With a Fragile Thread: A Story of Sisters and Africa (New York, Picador, 2006). Casting tells the story of the death of Wendy Kann's youngest sister Lauren. Lauren is killed in a car accident in rural Zambia. Her death forces Kann to return to Africa (she lives in suburban picket fence Connecticut) and reflect on her childhood, her relationship with her family (especially her sisters), and life in colonial Rhodesia.

${ }^{12}$ L. St John, Rainbow's End: A Memoir of Childhood, War \& an African Farm (London, Hamish Hamilton, 2007). Rainbow's End is a memoir of Lauren St John's life in Rhodesia. Unlike other memoirs St John's family 
actually moved back to Rhodesia from South Africa because her father did not want to be accused of dodging conscription.

${ }^{13}$ L. Liebenberg, The Voluptuous Delights of Peanut Butter and Jam (London, Little Brown, 2008). The Voluptuous Delights tells the story of two sisters, Nyree and Cia, living on a remote farm with their parents and grandfather during the liberation struggle. Unlike the other memoirs, the lines between novel and memoir are increasingly blurred in Liebenberg's writing. Nyree and Cia are generally more in touch with black African culture than the protagonists of other works. While war continually threatens the lives of Nyree and Cia, it is the malign presence of their illegitimate cousin Ronin that looms throughout the book.

${ }^{14}$ C. Clary, Useless, Worthless, Priceless (Manchester, Trafford, 2007). Useless, Worthless, Priceless is more a reflection on Clary's childhood and adolescence than a discussion of colonial life in Rhodesia. Yet as with many other writers the liberation struggle clearly impacted on Clary's sense of identity. Clary's book was self-published and thus is not as obviously literary as the others works discussed.

15 A. Harris, "Writing home: inscriptions of whiteness / descriptions of belonging in white Zimbabwean memoir / autobiography", in R. Muponde and R. Primorac (eds), Versions of Zimbabwe new approaches to literature and culture (Harare, Weaver Press, 2005), p. 108.

16 To get a sense of "black writing" see for instance, T. Dangarembga, Nervous Conditions (London, The Women's Press, 1988), idem The Book of Not (Banbury, Ayebia Clark Publishing, 2006); C. Hove, Bones (Harare, Baobab Books, 1988); D. Marechera, The House of Hunger (London, Heinemann, 1978); Y. Vera, Butterfly Burning (New York, Farrar, Straus and Giroux, 2000).

${ }_{17}$ T. Simoes da Silva "Redeeming Self: The Business of Whiteness in Post-Apartheid South African Writing” in A. Moreton-Robinson, M. Casey, and F. Nicoll (eds), Transnational Whiteness Matters (Plymouth, Lexington, 2008), p. 5.

${ }^{18}$ Harris, "Writing home", p. 117.

19 P. McLaren, "Whiteness in . . . The Struggle for Postcolonial Hybridity" in J. Kincheloe, S. Steinberg, N. Rodrigues and R. Chennault (eds), White Reign: Deploying Whiteness in America (New York, St Martin's Press, 1998), p. 66.

${ }^{20}$ B. Raftopoulos, "The Crisis in Zimbabwe, 1998-2008”, in B. Raftopoulos and A. Mlambo (eds), Becoming Zimbabwe: A History from the Pre-Colonial Period to 2008 (Harare, Weaver Press, 2009), p. 216.

${ }^{21}$ For further information see P. Murphy, "An Intricate and Distasteful Subject': British Planning for the Use of Force Against the European Settlers of Central Africa, 1952-65”. English Historical Review 121.492 (2006), pp. 746-77; C. Watts, Rhodesia's Unilateral Declaration of Independence: An International History (Basingstoke, Macmillan, 2012).

${ }^{22}$ For more on population demographics see J. Brownell, The Collapse of Rhodesia: Population Demographics and the Politics of Race (London, I.B. Tauris, 2010).

${ }^{23}$ For histories of the Chimurenga see M. Kesby, "Arenas for Control, Terrains of Gender Contestation: Guerrilla Struggle and Counter Insurgency Warfare in Zimbabwe 1972-1980", Journal of Southern African Studies, 2.4 (1996), pp. 561-584; N. Kriger, Zimbabwe's Guerrilla War (Cambridge, Cambridge University Press, 1991); I. Phimister, "The 
Combined and Contradictory Inheritance of the Struggle against Colonialism", Transformation 5 (1987) pp. 51-59.

${ }^{24}$ Chaired by British Foreign Secretary Lord Peter Carrington, the conference was attended by Ian Smith and Abel Muzorewa as leaders of the newly minted Rhodesia-Zimbabwe, as well as Robert Mugabe and Joshua Nkomo as leaders of the Patriotic Front (PF). Held over a three-month period, eventually reaching resolution in December 1979, the conference's main aims were to draft a post-independence constitution, to ensure that there would be a ceasefire, and to ensure that white interests would be represented in the new national order.

${ }^{25} \mathrm{~K}$. Alexander, "Orphans of the Empire: An Analysis of Elements of White Identity and Ideology Construction in Zimbabwe", in B. Raftopoulos and T. Savage (eds), Zimbabwe: Injustice and Political Reconciliation (Cape Town, Institute for Justice and Reconciliation, 2004), pp. 193-213.

${ }^{26}$ J. L. Fisher, Pioneers, Settlers, Aliens, Exiles The Decolonisation of White Identity in Zimbabwe (Canberra, ANU Press, 2010), p. 174.

27 Godwin and Hancock, Rhodesians Never Die, p. 3. For Godwin and Hancock, white Zimbabweans seemingly had three options in 1980. They could emigrate, remain behind and live in the past, or accept the realities of the situation and engage meaningfully with the Zimbabwean postcolonial state, p. 3.

${ }^{28}$ R. Mugabe, Address to the Nation by the Prime Minister Elect 4 March 1980 (published by the Ministry of Information, Immigration and Tourism, Zimbabwe, 1980).

${ }^{29}$ I. Mandaza, "The Post-White Settler Colonial State in Zimbabwe”, in I. Mandaza (ed.), Zimbabwe: The Political Economy of Transition (Dakar, Codesria, 1986), p. 56.

30 For now canonical texts see R. Dyer, White (London, Routledge, 1997), and D. Roediger, The Wages of Whiteness: Race and the Making of the American Working Class (New York, Verso, 1991). The discussion of whiteness literature in this piece is not meant to be exhaustive; rather it aims to demonstrate the ways in which whiteness studies have been discussed in some different disciplinary approaches. For an overview of the ways historians have used whiteness see L. Boucher, J. Carey and K. Ellinghaus, "Re-Orienting Whiteness: A New Agenda For the Field", in L. Boucher, J. Carey and K. Ellinghaus (eds), Re-Orienting Whiteness (London, Palgrave MacMillan, 2009), pp. 1-14.

${ }^{31}$ For further detail on the hegemony of whiteness see R. Shome, "Whiteness and the Politics of Location: Postcolonial Reflections", in T. K. Nakayama and J. N. Martin (eds), Whiteness The Communication of Social Identity (London, Sage Publications, 1999), pp. 107-129.

32 Dyer, White, p. 3.

33 R. Frankenberg, White Women, Race Matters: The Social Construction of Whiteness (Minneapolis, University of Minnesota Press, 1993), p. 1.

34 Ibid., p. 1.

35 Postcolonial studies initiated a recategorisation of the dominant paradigms of power. The discipline challenged the normative (white) categorisations associated with race, gender, ethnicity and sexuality, thereby confronting the elision of subaltern identities.

${ }^{36}$ R. Pilossof, The Unbearable Whiteness of Being: Farmers' Voices from Zimbabwe (Harare, Weaver Press, 2012).

37 M. E. Steyn, "Whiteness Just Isn't What it Used to Be" White Identity in a Changing South Africa (New York, University of New York Press, 2001), 
p. xxvi. For a discussion of "Afrikaner Whiteness" see also Steyn, "Rehabilitating a Whiteness Disgraced: Afrikaner White Talk in Post-Apartheid South Africa”, Communication Quarterly, 52.2 (2004), pp. 143-169. See also N. Roos, "The Springbok and the Skunk, War Veterans and the Politics of Whiteness in South Africa during the 1940s and 1950s", Journal of Southern African Studies, 35.3 (2009), pp. 643-661.

38 L. de Kock, "Blanc de Blanc: Whiteness Studies - A South African Connection?”, Journal of Literary Studies 22.1-2 (2006), pp. 175.

39 Ibid., p. 176.

${ }^{40}$ For further detail see A. Chennells, "Settler Myths and the Southern Rhodesian Novel", (PhD thesis, University of Zimbabwe, 1982).

41 See for instance A. Sparks, Tomorrow is Another Country: The Inside Story of South Africa's Negotiated Revolution (Wynberg, Struik Publishing Company, 1994). For a different reading of white reactions to the TRC see G. Theissen and B. Hamber, "A State of Denial: White South Africans' Attitudes to the Truth and Reconciliation Commission", Indicator South Africa 15.1 (1998), pp. 8-12.

${ }^{42}$ M. Chege, “Africans of European Descent”, Transition 73 (1997), p. 76.

43 S. Matthews, "Becoming African: Debating Post-Apartheid White South African Identities", African Identities 9.1 (2011), pp. 1-2.

${ }^{44}$ See for instance, S. Vice, "'How Do I Live in This Strange Place?' ", Journal of Social Philosophy, 41.3, (Fall 2010), p. 326. In relation to the Zimbabwean example, when reflecting on his fieldwork, David McDermottHughes offered the following: "I learned Shona, Zimbabwe's majority language. I conducted dissertation research in remote Ngorima Communal Land, eating sadza with the peasants at the foot of the Chimanimani Mountains. By 1997, my informants speculated, 'Amai venyu mutema?': Was my mother black? ... A few times, I 'passed' as part black." See Whiteness in Zimbabwe, p. xvi.

${ }^{45}$ D. Seddon, "'The story that follows is true': secret stealing and the habits of entitlement”, Scrutiny two: Issues in English Studies in Southern Africa 10.1 (2005), p. 91.

${ }^{46}$ Boucher, Carey and Ellinghaus, "Re-Orienting Whiteness", p. 2.

47 A. Woollacott, "Whiteness and the 'Imperial Turn' ", in Boucher, Carey and Ellinghaus (eds), Re-Orienting Whiteness (London, Palgrave MacMillan, 2009), pp.19-20.

48 See for instance, S. Macdonald, Margaret Venning - Rhodesian (London, Cassell, 1928), S. Macdonald, Susan Outside (London, Cassell, 1930), G. Page, Jill's Rhodesian Philosophy or the Dam Farm (London, Hurst and Blackett, 1910), G. Page, The Rhodesian (London, Hurst and Blackett, 1912), C. Stockley, Virginia of the Rhodesias (London, Hutchinson \& Co, 1904), D. Lessing, The Grass is Singing (London, Michael Joseph, 1949), H. Richards, Next Year Will Be Better (London, Howard B. Timmins, 1952), J. Rose Innes, Writing In the Dust (London, Andre Deutsch, 1968), and D. Anderson, The Toe-Rags a Memoir: The Story of a Strange Upbringing in Southern Rhodesia (London, Andre Deutsch, 1989).

49 S. Nuttall, "Subjectivities of Whiteness", African Studies Review 44.2 (September 2001), p. 115.

50 R. Primorac, "Southern States: New Literature From and About Southern Africa”, Journal Of Southern African Studies 36.1 (2010), p. 251.

${ }^{51}$ Anthony Chennells has convincingly argued that "ethnicity has a place in the creation of Zimbabwean literature where Shona, Ndebele and 
white-authored texts are studied as discrete literatures”, thus Zimbabwean literature should not be seen as limited to a single canon. See Chennells, "Self-representation and national memory: white autobiographies in Zimbabwe", in Robert Muponde and Ranka Primorac (eds), Versions of Zimbabwe new approaches to literature and culture (Harare, Weaver Press, 2005), p. 135.

52 T. Simoes Da Silva, "Narrating A White Africa: Autobiography, Race and History", Third World Quarterly 26.3 (2005), p. 472.

53 There is a remarkable continuity in the design of the covers of Fuller's, St John's and Liebenberg's work. For a discussion of Africa as a "dialectic space" rather than geographical entity see J. Ferguson, Global Shadows: Africa in the Neoliberal World Order (North Carolina, Duke University Press, 2006). I am grateful to Neil Roos for bringing this reference to my attention.

54 See also B. Wainaina, "How to Write about Africa”, Granta 92 (2005), pp. 92-95.

55 See for instance McDermott-Hughes, Whiteness in Zimbabwe.

${ }^{56}$ Clary, Useless, p. 36.

57 A. Fuller, Scribbling the Cat: Travels with an African Soldier (London, Viking Penguin, 2004).

58 Interview with Fuller, available at http://www.powells.com/blog/ interviews/back-to-africa-with-alexandra-fuller-by-dave/, retrieved on 23 January 2012.

59 For a discussion of Scribbling the Cat see: A. M. Rauwerda, "Exile Encampments: Whiteness in Alexandra Fuller's Scribbling the Cat: Travels with an African Soldier", The Journal of Commonwealth Literature 44.2 (2009), pp. 44-51.

60 As a point of comparison it is interesting to note the active role that many black children played in the liberation struggle. Often acting as entrusted Mujibas (Shona "eyes and ears"), Mujibas would act as informants, track the position of the Rhodesian security forces and deliver food to guerrilla fighters. Black children also played an active role as combatants being trained in host countries and returning to fight in the War. As Norma Kriger has aptly demonstrated, while the recruitment of children and indeed the peasant community as a whole may have depended more on coercion than political commitment, it is nonetheless interesting to note the active role of black children compared to the passivity of their white counterparts. While a reductive reading of the passivity of white children may attempt to use the writer's gender as an explanation it is important to note the role that black girls played as Chimbwedos (Shona, female equivalent to Mujiba). See Kriger, Zimbabwe's Guerrilla War; R. Muponde, "Children of Resistance: Childhood, History and the Production of Nationhood in Two Zimbabwean Novels", in R. Muponde and R. Primorac (eds), Versions of Zimbabwe: New Approaches to Literature and Culture (Harare, Weaver, 2005), pp. 119-130.

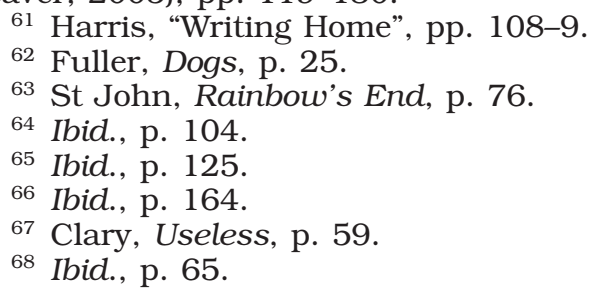


69 Ibid., p. 36.

70 Ibid., p. 58.

71 Fuller, Dogs, p. 146.

${ }^{72}$ Kann, Casting, p. 139.

73 St John, Rainbow's End, p. 193.

${ }^{74}$ Ibid., pp. 151-2.

${ }^{75}$ For a brief yet erudite discussion of white belonging and the ambiguities that this raises see J. Haggis, "Beyond Race and Whiteness? Reflections on the New Abolitionists and an Australian Critical Whiteness Studies”, Borderlands 3.2 (2004), pp.1-9.

76 St John, Rainbow's End, p. 191.

77 Ibid., p. 193.

${ }^{78}$ Fuller, Dogs, pp. 147-8. This is presumably a reference to Bishop Abel Muzorewa's defeat to Robert Mugabe.

${ }^{79}$ Liebenberg, The Voluptuous Delights, p. 231.

${ }^{80}$ Fuller, Dogs, p. 249.

81 Ibid., p. 250.

${ }^{82}$ Fuller, Dogs, pp. 7-8.

83 St John, Rainbow's End, p. 209.

84 Ibid., p. 192.

85 Ibid., p. 212.

${ }^{86}$ Ibid., p. 247. The emphasis is mine.

87 Coetzee, White Writing, p. 11.

88 St John, Rainbow's End, p. 247.

89 Kann, Casting, p. 130.

90 Ibid., p. 149.

91 St John, Rainbow's End, p. 196.

${ }^{92}$ Interview with Wendy Kann, January 2012.

93 Harris, "Writing Home", p. 105.

94 Interview with Wendy Kann, January 2012.

95 St John, Rainbow's End, p. 214.

96 Kann, Casting, p. 214.

97 See Chennells, "Settler Myths", p. xviii.

98 See McDermott-Hughes, Whiteness in Zimbabwe.

99 Ibid., p. 5.

100 Ibid., p. 5.

101 Fuller, Dogs, p. 8.

102 Ibid., p. 35.

103 A. Fuller, Cocktail Hour Under the Tree of Forgetfulness (New York, Penguin Group, 2011), p. 110.

104 Ibid., p. 16.

105 Fuller, Dogs, p. 28.

106 See for instance see B. Raftopoulos, "The State in Crisis: Authoritarian Nationalism, Selective Citizenship and Distortion of Democracy in Zimbabwe", in A. Hammar, B. Raftopoulos and S. Jensen (eds.), Zimbabwe's Unfinished Business: Rethinking Land, State and Nation in the Context of Crisis (Harare, Weaver Press, 2003), pp. 217-42.

107 "Zuma: 'It is only the Afrikaners who are truly South African' ”, Mail \& Guardian, 3 April 2009, available at http://mg.co.za/article/2009-0403-zuma-only-the-afrikaners-who-are-truly-south-africans, retrieved on 5 August 2012.

108 Pilossof, The Unbearable Whiteness of Being: Farmers' Voices, p. 3 . 
109 N. Manheru, "Zimbabwe: The paradox of the white African", Herald, 20 July 2012, available at http://www.herald.co.zw/index.php?option =com_content\&view=article\&id=47833:zimbabwe-the-paradox-of-the -white-african\&catid=59:manheru, retrieved on 23 July 2012. Nathaniel Manheru is the pen name of George Charamba, press secretary to Robert Mugabe.

110 Ibid.

111 J. D. Jansen, Knowledge in the Blood: Confronting Race and the Apartheid Past (Stanford, Stanford University Press, 2009), p. 267.

112 Pilossof, The Unbearable Whiteness of Being: Farmers' Voices.

113 A. Stoler and F. Cooper, "Between Metropole and Colony: Rethinking a Research Agenda", in F. Cooper and A. Stoler (eds), Tensions of Empire: Colonial Cultures in a Bourgeois World (Los Angeles, University of California Press, 1997). 